http://dx.doi.org/10.12775/szhf.2019.020

Karol Michalski

Uniwersytet Opolski, Opole, Polska

ORCID: 0000-0001-9815-4750

E-MAIL: K.MICHALSKI@AON.AT

\title{
Nerwice noogenne jako cierpienie na bezsens życia w logoterapii i analizie egzystencji Viktora E. Frankla
}

Punktem wyjścia i celem wspólnoty pracy między lekarzem i pacjentem $w$ leczeniu nerwicy jest pytanie o sens życia.

Leonhard Seif, Die Zwangsneurose

Sens zajmuje centralne miejsce w logoterapii i analizie egzystencji Viktora E. Frankla. Sens nie jest czymś pewnym, co stale towarzyszy życiu. Człowiek jako istota skończona, podlegająca rozpadowi, nieustannie zagrożony jest zachwianiem poczucia sensu. Kiedy pojawi się nerwica, ludzie zaczynają wątpić w sens życia. Dla cierpiącego na nerwicę nawet wykonywanie codziennych czynności może stać się problematyczne. Zaburzenia nerwicowe potrafią zmienić nasz sposób odnoszenia do siebie samych, innych i otaczającego świata. Człowiek, który powątpiewa w sens życia, zaniedbuje siebie, zrywa 
relacje z innymi, oddala się od bliskich, porzuca wykonywane zadania, odwraca się od świata. Zdarza się, że utrata sensu życia nie jest jednym z objawów nerwicy, ale jest jej istotą. Wówczas mamy do czynienia z nerwicą, która wstrząsa fundamentami ludzkiej egzystencji.

\section{Fenomen nerwicy noogennej w kontekście różnorodności zaburzeń neurotycznych}

Zaburzenia afektywne zawsze nękały człowieka, który lepiej lub gorzej radzi sobie ze swoimi problemami. Nieustannie poszukujemy sposobu na uporządkowanie własnej emocjonalnej relacji do świata i opanowanie wewnętrznej nerwowości. Jednocześnie czynimy wysiłki na rzecz rozpoznania przyczyny zachwiania równowagi afektywnej i ustalenia metod łagodzenia jej niezdrowych objawów. „Każda epoka ma swoje nerwice i każda epoka potrzebuje ich psychoterapii. Dzisiaj my, psychiatrzy, mamy mniej do czynienia z klasycznymi formami nerwicy, a raczej z jej nowym rodzajem" ${ }^{1}$. Zaburzenie neurotyczne, o którym mówi Frankl, na ogół wynika z emocjonalnego napięcia między wymaganiami, jakie stawia otoczenie, i możliwościami sprostania im. Sytuacja życiowa może ode mnie wymagać, abym wykonał zadanie, zniósł cierpienie, przezwyciężył samotność. Jeżeli wymagania otoczenia przybierają na sile, to powstaje trudne do zniesienia napięcie. Sposób reagowania na nie zależy od indywidualnej wrażliwości i odporności emocjonalnej. Bywa, że człowiek jest bezradny wobec narastającej presji. Niemoc, pociągająca za sobą niezdolność do rozładowania negatywnych emocji, powoduje pęknięcie w duszy, prowadzi do depresji i kwestionowania sensu życia. „Pacjenci zwracają się do psychiatry, ponieważ wątpią w sens swojego życia albo zupełnie tracą nadzieję na znalezienie jakiegokolwiek sensu. Mamy do czynienia z nowym typem nerwicy, który nazwałem nerwica noogenną"2. Uwidacznia się ona w wymiarze duchowym (nous - duch), w którym człowiek poszukuje sensu i może doznawać kryzysu sensu. Współczesny fenomen nerwicy no-

\footnotetext{
${ }^{1}$ Viktor E. Frankl, Psychotherapie für den Laien (Freiburg im Breisgau: Herder, 1978), 11.

${ }^{2}$ Viktor E. Frankl, Ärztliche Seelsorge. Grundlagen der Logotherapie und Existenzanalyse. Mit den „Zehn Thesen über die Person“ (Bern: Hans Huber, 2015), 20.
} 
ogennej odsyła do XIX stulecia, gdy rozpoznano „nowy rodzaj psychicznego cierpienia”, który nie objawiał się „,ani jako szaleństwo, ani jako choroba organiczna", a z którym medycyna do dzisiaj nie może sobie właściwie poradzić3. To przejawiające się $\mathrm{w}$ różnych patologicznych formach psychiczne cierpienie zostało nazwane nerwicą. Psychoanaliza jest pierwszą próbą wyjścia naprzeciw nerwicowym zaburzeniom psychicznym. Zbudowanie jej podstaw przez Freuda dało początek współczesnej psychiatrii.

Godzina narodzin psychoterapii wybiła wtedy, kiedy dostrzeżono, że za symptomami cielesnymi kryją się przyczyny psychiczne, a zatem odkryto ich psychogenezę; teraz jednak trzeba zrobić jeszcze jeden krok i zza tego, co psychogenne, zza afektywnej dynamiki nerwicy, wydobyć człowieka w jego duchowej biedzie - aby od tej strony mu pomóc ${ }^{4}$.

O ile nerwica psychogenna została rozpoznana w związku z przemianami społeczeństwa przemysłowego, o tyle we współczesnych przeobrażeniach cywilizacyjnych, które destrukcyjnie działają na człowieka, Frankl widzi przyczynę powstania nerwicy noogennej ${ }^{5}$. Nerwicę noogenną, w odróżnieniu od zaburzenia psychicznego, nie określa chorobą, ale „cierpieniem na bezsens życia (das Leiden am sinnlosen Leben)"'.

We wprowadzeniu do logoterapii i analizy egzystencji zatytułowanym Theorie und Therapie der Neurosen Frankl dokonuje oryginalnego, ugruntowanego w psychoterapeutycznej praxis, uporządkowania zaburzeń nerwicowych oraz określa psychoterapeutyczną pozycję ich leczenia.

Każda teoria i terapia nerwic ma się poruszać po drabinie do nieba, stojącej na podłożu klinicznym, jednak sięgającej ku przestrzeni metaklinicznej. Ze względów badawczych i dla celów dydaktycznych trzeba postąpić tak, jakby istniało coś takiego, jak wyraźne szczeble tej drabiny Jakubowej: właściwie nie istnieją nerwice czysto somatogenne, psychogenne i noogenne, lecz raczej mamy do czynienia z przypadkami mieszanymi - przypadkami, w których na czoło po-

${ }^{3}$ Horst-Eberhard Richter, Die Gruppe. Hoffnung auf einen neuen Weg, sich selbst und andere zu befreien (Hamburg: Rowohlt, 1995), 11.

${ }^{4}$ Frankl, Ärztliche, 35.

${ }^{5}$ Uwe Böschemeyer, Die Sinnfrage in Psychotherapie und Theologie. Die Existenzanalyse und Logotherapie Viktor E. Frankls aus der theologischer Sicht (Berlin: De Gruyter, 1977), 13.

${ }^{6}$ Viktor E. Frankl, Die Sinnfrage in der Psychotherapie (München: Piper, 1996), 51. 
glądów teoretycznych i zamiarów terapeutycznych wysuwa się raz moment somatogenny, innym razem psychogenny lub noogenny ${ }^{7}$.

W logoterapii pierwszy kontakt z zaburzeniem nerwicowym jest zetknięciem się nie z chorobą, lecz ze sposobem bycia cierpiącego człowieka. Frankl dystansuje się od nozologicznego (nozos - choroba) systemu klasyfikowania schorzeń, przyporządkowującego indywiduum do pewnej grupy według określonego schematu. Fenomenów patologicznych Frankl nie postrzega przez pryzmat klasyfikacji nozologicznej, lecz ujmuje je w swoistości ich objawiania się. Nie dopasowuje choroby do określonej metody leczenia, ale dostosowuje metodę do złożonego zaburzenia nerwicowego. Wychodząc poza metody kliniczne, stara się znaleźć najlepszą terapeutyczną odpowiedź na nerwicę mającą skomplikowane pochodzenie i objawy.

Od pewnego czasu toczy się dyskusja na temat znaczenia pojęcia nerwicy. Dyskusja ta została zdominowana przez tych, którzy traktują nerwicę jako chorobę, i przez tych, którzy rozszerzają znaczenie pojęcia nerwicy, rozumiejąc ją jako syndrom, zespół objawów. Niektórzy domagają się w ogóle zniesienia pojęcia nerwicy ${ }^{8}$. Frankl, wybierając drogę pośrednią, wprowadza rozróżnienie między nerwicą we właściwym, węższym sensie tego słowa, a nerwicą w dalszym, pochodnym znaczeniu. W ścisłym sensie nerwicą jest nerwica psychogenna, tzn. zaburzenie powstałe w obszarze tego, co psychiczne.

Obok nerwicy w ściślejszym sensie tego słowa znamy też nerwice w szerszym znaczeniu, przykładowo somatogenne, noogenne, socjogenne (pseudo)nerwice. Jeżeli chodzi o te nerwice, to mamy do czynienia $\mathrm{z}$ nerwicami w sensie klinicznym. Lecz istnieją także nerwice w sensie metaklinicznym i paraklinicznym. Do tych ostatnich należą nerwice kolektywne. Są one quasi-nerwicami, nerwicami w przenośnym sensie?

${ }^{7}$ Viktor E. Frankl, Theorie und Therapie der Neurosen. Einführung in Logotherapie und Existenzanalyse (München: Ernst Reinhardt: 2007), 7.

${ }^{8}$ Obecnie na zachodzie Europy odchodzi się od nazwy „nerwica”, ze względu na złożony patogenetyczny i symptomatologiczny charakter zmieniając ją na określenie „zaburzenie psychiczne" (psychische Störung, mental disorder).

${ }^{9}$ Frankl, Logotherapie, 114. 
Nerwica kolektywna jest zjawiskiem społecznym, wyrażającym „patologię ducha czasu"10. Jako pseudonerwica jest w pewnym sensie chorym sposobem bycia. Z punktu widzenia logoterapii nerwica kolektywna nosi w sobie potencjalne zagrożenie dla zdrowia. Dla Frankla zdrowie dotyczy człowieka we wszystkich jego wymiarach, także egzystencjalnym. Człowiek może cierpieć na ból głowy, choroby układu krążenia, depresję, schizofrenię, ale może też odczuwać bezsens życia albo ulegać bezwiednie cierpieniu, które zaburza rozwój jej egzystencji. Kolektywność oznacza nie tylko to, że nerwica o takim charakterze może dotyczyć większej grupy ludzi, ale przede wszystkim, że człowiek nie żyje swoim własnym życiem.

Nerwica kolektywna według logoterapii i analizy egzystencji Frankla przejawia się w czterech symptomach ${ }^{11}$ :

1. Prowizoryczna postawa bycia ludzkiego. Życie prowizoryczne to życie niezakorzenione $\mathrm{w}$ świecie, niezwiązane $\mathrm{z}$ losami Ziemi. W prowizorycznej postawie człowiek nie widzi konieczności działania i brania losu w swoje ręce. Osoba żyjąca w ten sposób nie uświadamia sobie wolności do odpowiedzialnego kształtowania siebie i świata.

2. Fatalistyczne nastawienie do życia. „Dzisiejszy człowiek jest opętany przez przesądną wiarę $\mathrm{w}$ najprzeróżniejsze moce rządzące losem, a współczesny nihilizm odżywia jeszcze tę wiarę w przeznaczenie"12. Przez nihilizm Frankl rozumie odrzucanie wolności i odpowiedzialności działania. Człowiek fatalistyczny obwinia za swoją sytuację położenie społeczne albo dziedziczne uwarunkowania. Obarcza odpowiedzialnością anonimowe instytucje, rodzinę, szkołę, pracodawcę. Uważa siebie za zależnego od struktur, ludzi, układów, charakteru, wzorców postępowania albo kosmicznych sił, które akceptuje jako nieuniknione. Ponieważ człowiek nie czuje się wolny, tylko zależny od różnych elementów, dlatego nie poczuwa się do odpowiedzialności za siebie, innych, świat.

3. Myślenie kolektywistyczne. Polega ono na wyrzeczeniu się osobowego myślenia na rzecz masowego, obiegowego, bezosobowego myślenia.

\footnotetext{
10 Tamże, 285.

${ }^{11}$ Frankl, Theorie, 158.

12 Tamże, 159.
} 
Ulegający kolektywistycznemu myśleniu człowiek rezygnuje z wolności własnego myślenia, za które ponosi odpowiedzialność. Utrwalone modele kolektywistycznego myślenia określają sposób wyrażania się i zachowania.

4. Fanatyzm. Kolektywistyczne myślenie prowadzi do fanatyzmu. „Jeżeli myślący kolektywistycznie ignoruje swoją własną osobowość, to fanatyk ignoruje osobowość myślącego inaczej”' ${ }^{13}$. Dla fanatyka myślenie inne jest nieważne. Fanatyk kwestionuje wolność myślenia drugiego człowieka.

Nie istnieje bezpośredni związek zdrowia psychicznego z nerwicą kolektywną. Zdrowi na ciele i duszy ludzie mogą tak samo ulegać nerwicy kolektywnej, jak neurotycy w klinicznym sensie. Postawieni na ławie oskarżonych przestępcy wojenni, gdy poddano ich badaniom psychiatrycznym, okazali się klinicznie zdrowi. Ideologiczni fanatycy i terroryści, którzy wpadli w ręce sprawiedliwości i zostali przebadani psychiatrycznie, nie zdradzali objawów zaburzeń psychicznych, lecz silne symptomy nerwicy kolektywnej.

Wiemy, że nie tylko konflikt psychiczny, ale także duchowy, przykładowo konflikt sumienia, może prowadzić do nerwicy. Określamy ją jako nerwicę noogenną. Jest rzeczą zrozumiałą, że dopóki człowiek jest w ogóle zdolny do doświadczenia konfliktu sumienia, to będzie on zaprawiony przeciwko fanatyzmowi czy nerwicy kolektywnej. I odwrotnie, ktoś, kto cierpi na nerwicę kolektywną, a więc na przykład ktoś politycznie sfanatyzowany, może stać się w tym samym stopniu zdolny przezwyciężyć swoją nerwicę kolektywną, w jakim będzie w stanie usłyszeć głos swojego sumienia czy nawet cierpieć z powodu tej nerwicy ${ }^{14}$.

Jeżeli możliwa jest zależność zdrowia klinicznego od nerwicy kolektywnej, tzn. neurotycy kolektywni z powodu wzrastającego obciążenia sumienia mogą załamać się nerwowo, to relacja nerwicy kolektywnej do nerwicy noogennej jest odwrotnie proporcjonalna: im bardziej ktoś jest opanowany przez kolektywną nerwicę, tym mniejsze jest prawdopodobieństwo, że doświadczy kryzysu sensu. Im mniej ktoś poddaje się nerwicy kolektywnej, w tym większym stopniu może ulec nerwicy noogennej. Przynależność do

\footnotetext{
13 Tamże.

${ }^{14}$ Tamże, 160.
} 
kolektywu nie jest cechą ludzi podatnych na przeżycie bezsensu. Nieustannie karmieni fanatyzmem ideologiczni funkcjonariusze stają się odporni na kryzysy sensu. O ile podatność na konflikt sumienia związana z kryzysem egzystencjalnym chroni przed uleganiem nerwicy kolektywnej, o tyle fanatyzm jest jej nośnikiem. Neurotyczny fanatyzm może siedzieć głębiej w człowieku niż kryzys sensu, dlatego jest trudniejszy do wyleczenia.

Wszystkie cztery symptomy kolektywnej nerwicy: prowizoryczna postawa bycia ludzkiego, fatalistyczne nastawienie, kolektywistyczne myślenie i fanatyzm - sprowadzają się do ucieczki przed odpowiedzialnością i lękiem przed wolnością. Wolność i odpowiedzialność tworzą duchowość człowieka. Dzisiejszy człowiek jest duchowo zniechęcony i to duchowe zniechęcenie jest właśnie istotą współczesnego nihilizmu ${ }^{15}$.

Przezwyciężanie obojętności i lęku związanego z dokonywaniem wolnego wyboru oraz z odpowiedzialnym decydowaniem na przekór dziedzicznym, psychologicznym, socjologicznym uwarunkowaniom i ideologicznym wpływom jest nie tylko obroną przed popadnięciem w nerwicę kolektywną, ale też drogą do budowania własnego sensu życia ${ }^{16}$. Człowiek nie znajdzie sensu życia, jeżeli usiłuje go przejąć od innych albo przyjmuje to, co się masowo i powszechnie uważa za sensowne. Wbrew „kolektywizacji sensu” logoterapia uczy, że od każdego zależy szukanie i znalezienie konkretnego sensu swojego osobistego bycia.

Dopiero w poświęceniu się pewnej rzeczy kształtujemy własną osobę. Nie dzięki obserwowaniu siebie samego lub oglądaniu siebie w zwierciadle, nie dzięki zezwoleniu na krążenie myślenia wokół naszego strachu staniemy się wolni od tego strachu, lecz w wyniku rezygnacji z siebie, wydania siebie, poświęcenia siebie rzeczy wartej temu poświęceniu. To jest tajemnica wszelkiego kształtowania siebie, i nikt inny nie wyraził tego trafniej, niż Karl Jaspers, kiedy pisze: „Tym, czym człowiek jest, tym jest przez rzecz, którą sobie przyswoił"17.

\footnotetext{
15 Tamże.

${ }^{16}$ Alexander Battyany, Die Überwindung der Gleichgültigkeit. Sinnfindung in einer Zeit des Wandels (München: Kösel, 2017), 112.

${ }^{17}$ Frankl, Logotherapie, 180.
} 
Przez strach Frankl rozumie neurotyczny lęk, paraliżujący możliwości wykraczania poza siebie i oddania się czemuś, kiedy człowiek boi się nawet opuścić swoje mieszkanie. Lęk ten ugruntowany jest w strachu egzystencjalnym mającym źródło w świadomości zagrożenia śmiercią i troską o zachowanie własnego życia. To, jak potrafimy przezwyciężyć strach o siebie, i to, z czym się utożsamiamy, to kształtuje sens naszego życia. „Ostatecznie kryzysy tożsamości są kryzysami sensu”18. Sens swojej egzystencji budujemy na wartościach, z którymi się utożsamiamy. Jeżeli człowiek przeżywa kryzys sensu, to znaczy, że to, z czym się utożsamia i czemu się poświęca, nie daje mu żadnego lub wystarczająco mocnego fundamentu, na którym może opierać swoje życie. Głębokie poczucie sensu oznacza, że to, z czym się utożsamiamy i czemu się oddajemy, stanowi solidny fundament naszej egzystencji. Pytanie o sens jest zawsze pytaniem o tożsamość - o to, z czym się utożsamiamy.

\section{Powstanie nerwic noogennych}

W postrzeganiu bycia ludzkiego analiza egzystencji wykracza poza wymiar tego, co psychiczne, i tego, co somatyczne, i wchodzi w trzeci wymiar duchowy, „ponieważ obok tego, co somatyczne i psychiczne, istnieje własny wymiar tego, co duchowe - ale nie tylko to; lecz jest to właściwy wymiar bycia ludzkiego"19. Przez wymiar duchowy Frankl rozumie to, co najbardziej ludzkie w człowieku. Duchowość jest miejscem, w którym mogą powstawać szczególne neurotyczne zaburzenia, które mają wpływ na zdrowie całego człowieka.

Także $\mathrm{w}$ tym wymiarze mogą być zakorzenione nerwice - mówimy wtedy o nerwicach noogennych (powstałych $\mathrm{z}$ tego, co duchowe); ponieważ także człowiek, który stoi wobec konfliktu sumienia albo pod presją duchowego problemu, a także człowiek doświadczający kryzysu egzystencjalnego, może zachorować neurotycznie ${ }^{20}$.

\footnotetext{
${ }^{18}$ Frankl, Die Sinnfrage, 38.

${ }^{19}$ Frankl, Theorie, 150.

${ }^{20}$ Tamże.
} 
W odróżnieniu od rozpowszechnionych w psychologii egocentrycznych teorii motywacyjnych, które wychodzą od podstawowego dążenia człowieka do dobrego samopoczucia, samozadowolenia, indywidualnych korzyści, pozycji, władzy, Frankl rozwinął własny „teoretyczno-motywacyjny pomysł woli sensu"21. Jego obraz człowieka, obdarzonego wolą sensu, tzn. zdolnością do wybierania i podążania za tym, co sensowne, kontrastuje z Freudowskim obrazem człowieka sterowanego pędem do przyjemności i Adlera obrazem człowieka kierującego się żądzą władzy. „Lecz o wiele głębiej zakorzenione jest w człowieku to, co określamy jako wolę sensu: jego zmaganie o wypełnienie sensem swego ludzkiego bycia"22. Cierpiący na nerwicę często ulega wrażeniu, że mógłby zmienić swoje położenie, ale brakuje mu na to duchowych sił. Logoterapia Frankla postawiła sobie za zadanie pobudzać w człowieku wolę sensu i na nowo ją ożywiać, kiedy zgasła.

Idea woli sensu nie powinna być opacznie rozumiana w sensie jakiegoś apelu do woli. Wiara, miłość, nadzieja nie pozwalają się manipulować i fabrykować. Nikt nie może ich nikomu rozkazać. Wymykają się one nawet działaniu własnej woli. Nie mogę chcieć wierzyć, nie mogę chcieć kochać, nie mogę chcieć ufać a przede wszystkim nie mogę chcieć chcieć. Dlatego daremne jest wymagać od człowieka, aby „chciał sensu”. Apelować do woli sensu oznacza raczej pozwolić, aby sens sam się ukazał - i pozwolić woli na to, aby go chciała ${ }^{23}$.

Poszukiwanie sensu nie jest tylko sprawą woli, ale także sprawą poznania, które odkrywa rzecz godną spełnienia. Człowiek musi sam dostrzec coś, czego urzeczywistnienia zapragnie. Opanowany przez lęki i depresje, człowiek zagubił wolę sensu i w ogóle wolę życia. Każdy, kto chce żyć, pragnie sensu, ale nie każdy ma wystarczająco silną wolę, by o niego walczyć. Zdarza się, że ktoś ukierunkuje swoje dążenie na coś, co nie wypełni go wystarczająco mocnym sensem. „Ludzka wola sensu może także być sfrustrowana, w tym przypadku logoterapia mówi o frustracji egzystencjalnej”24. Niezrealizowane dążenie do sensu, brak życiowego zadania, poczucie braku celu i treści ży-

\footnotetext{
${ }^{21}$ Tamże, 214.

22 Tamże, 164.

${ }^{23}$ Viktor E. Frankl, Der Mensch vor der Frage nach dem Sinn (München: Piper, 2015), 224.

${ }^{24}$ Viktor E. Frankl, Grundkonzepte der Logotherapie (Wien: Facultas, 2015), 15.
} 
cia pozostawia pustkę, którą Frankl nazywa "pustką egzystencjalną" ${ }^{25}$. Staje się ona miejscem, gdzie budzą się obce siły - kompleksy, fobie, natręctwa, depresje, lęki. Pusta przestrzeń może wypełnić się pseudotreściami (agresja, uzależnienia, przestępczość), które nazywa Frankl „zamaskowanymi nerwicami”. Czasami człowiek, zanurzony w wir życia codziennego, nie jest świadomy nerwicy, która mu towarzyszy i w nim narasta. Nerwicę, która ujawnia się w tzw. wolnym czasie, nazywa Frankl „nerwicą niedzielną” (Sonntagsneurose $)^{26}$. Wtedy - paradoksalnie - szczególnie daje o sobie znać ukryty kryzys sensu, przejawiający się w załamaniach nerwowych i próbach samobójczych.

Egzystencjalna frustracja może także prowadzić do pewnej nerwicy. Dla tego rodzaju nerwicy logoterapia ukształtowała pojęcie „nerwicy noogennej”, w odróżnieniu od nerwic w tradycyjnym sensie tego słowa, czyli nerwic psychogennych ${ }^{27}$.

Nerwica rodzi się z konfliktu wewnętrznego. Według Freuda jej przyczynami są niezaspokojone pożądania, nieprzyjemne przeżycia i nieprzystosowanie do codziennych obciążeń. Przeżycia konfliktowe, powstałe w sytuacjach powszednich, zostają wypierane do nieświadomości, gdzie rodzą się zaburzenia objawiające się w świadomym życiu. Przyczyną nerwic noogennych są konflikty, sięgające o wiele głębiej niż konflikty powstałe w obszarze psychiki. „Nerwice noogenne nie wynikają z konfliktów między popędami i instynktami, ale z egzystencjalnych problemów. Wśród nich frustracja woli sensu odgrywa ważną rolę"28. Konflikty są nieuniknione, ponieważ człowiek ma wolność powiedzenia „nie” Bogu, tradycji, prawu, władzy, społeczeństwu, naszej przeszłości albo własnemu instynktowi zachowania życia. Każda chwila wymaga od nas decyzji, każda decyzja nosi w sobie konflikt, a każdy konflikt rodzi napięcia, które mogą zamienić się w nerwicę. W szybko zmieniającym się świecie człowiek stoi ciągle przed decyzją wyboru między starymi i nowymi wartościami: między wartością robienia kariery a wartością niezależności, między dobrze płatnym, lecz niesatysfakcjonującym stanowi-

\footnotetext{
${ }^{25}$ Frankl, Theorie, 156.

${ }^{26}$ Frankl, Logotherapie, 118.

${ }^{27}$ Frankl, Grundkonzepte, 16.

${ }^{28}$ Tamże, 17.
} 
skiem a pracą pozwalającą rozwinąć twórcze możliwości. Wiele wewnętrznych konfliktów, których doświadcza współczesny człowiek, ma związek $\mathrm{z}$ tego typu wyborami ${ }^{29}$. Kiedy robimy coś wbrew swojemu sumieniu, swoim najgłębszym odczuciom, wbrew sobie - tzn. wbrew swojemu wewnętrznym dążeniu do sensu - wtedy mogą powstać konflikty objawiające się w postaci nerwic noogennych ${ }^{30}$. Poszukując przyczyn nerwic, powstałych w wymiarze duchowym, Frankl sięga po słowa swojego nauczyciela Rudolfa Allersa: „Nie widziałem jeszcze żadnego przypadku nerwicy, w którym nie ujawniłoby się jako ostateczny problem i jako ostateczny konflikt, nazwijmy to, nierozwiązane pytanie metafizyczne" ${ }^{\prime 1}$. Jest to pytanie o sens - pytanie o to, co daje mojemu ludzkiemu byciu fundament, aby mogło ono się sensownie rozwijać. Jaka idea wiodąca, jaki człowiek, jaka rzecz, jaki Bóg, jakie życiowe zadanie mogą być podwalinami mojego życia. Niewłaściwe wybory drogi życiowej, błędne decyzje dotyczące innych ludzi, działania na szkodę własną i drugiego, bezsilność w obliczu utraty życia i cierpienia innych - wszystko to może rodzić problemy egzystencjalne, które przemienią się w nerwicę. Aby uniknąć konfliktu sumienia i kolizji wartości, które niosą ze sobą potencjalne ryzyko nerwicy noogennej, ludzie rezygnują z niektórych profesji, przechodzą na wegetarianizm lub weganizm, unikają działań wystawiających na ryzyko życie swoje lub innych. Ostatecznie każde działanie na szkodę jakiejkowiek istoty żywej nie pozostaje bez śladu w duchowej przestrzeni człowieka i może obrócić się przeciwko niemu w postaci nerwicy. Uleganie jakiemukolwiek złu jest nerwicogenne.

Zmienia się świat, zmienia się człowiek, zmieniają się przyczyny zaburzeń nerwicowych. Kiedyś wielu pacjentów było przytłoczonych poczuciem winy wobec rodziców, społeczeństwa, Boga. Współcześnie stany nerwicowe odnoszą się raczej do zdrowia, zdolności zarabiania pieniędzy, życia zawodowego, starzenia się. Depresje pacjenta naszych czasów, jak wyraził się kiedyś Frankl,

\footnotetext{
${ }^{29}$ Josef B. Fabry, Das Ringen um Sinn (Stuttgart: Paracelsus, 1973), 41.

${ }^{30}$ Ostatnio częstymi pacjentami gabinetów psychoterapeutycznych są frustrowani pracownicy bankowi. Nie do wytrzymania staje się dla nich konflikt sumienia wywołany stosowaniem, przy coraz większym nacisku kierownictwa, wyrafinowanych, wykorzystujących techniki manipulacji, sposobów pozyskiwania klienta.

${ }^{31}$ Rudolf Allers, Das Werden der sittlichen Person (Wildesheim-New York: Georg Olms, 1979), 283.
} 
„mniej wynikają z winy (Schuld), a bardziej z długów (Schulden)”32. Logoterapia nie tylko służy terapii nerwic, niezależnie od tego, na jakim powstały podłożu, ale także uczy umiejętności wybierania takich możliwości urzeczywistniania sensu, które chronią przed kryzysem i załamaniem.

\section{Leczenie nerwic noogennych}

Frankl określa logoterapię jako specyficzny rodzaj leczenia nerwic noogennych, który uwględnia egzystencjalny charakter (kolizje wartości, konflikty sumienia) nerwic noogennych. Jest przekonany, że bycie chorym na duszy może mieć źródło zarówno w wymiarze somatycznym (nadczynność lub niedoczynność tarczycy), jak i psychicznym (traumy dziecięce) czy noetycznym (konflikty duchowe). Psychiatra przy stawianiu diagnozy nie może pominąć żadnego z tych wymiarów. Musi postrzegać pacjenta w sposób całościowy.

Jest rzeczą jasną, że w przypadkach nerwicy noogennej zwyczajna psychoterapia ogólna nie może być odpowiednią i adekwatną psychoterapią; tu jest właśnie wskazana logoterapia, to znaczy terapia, która waży się wniknąć w specyficznie ludzki wymiar ${ }^{33}$.

Pewnego razu do gabinetu psychiatrycznego Frankla we Wiedniu przyszedł wysoko postawiony amerykański dyplomata, aby kontynuować leczenie, które przed pięciu laty rozpoczął u pewnego nowojorskiego psychonalityka. Okazało się, że pacjent był niezadowolony z wykonywanego zawodu i miał trudności z identyfikowaniem się z amerykańską polityką zagraniczną. Jego psychonalityk ciągle przekonywał go, że powinien spróbować pojednać się ze swoim ojcem. Według niego bowiem amerykański rząd i przełożeni pacjenta mieli być odpowiednikami obrazu jego ojca, a niezadowolenie z pracy było ugruntowane $\mathrm{w}$ nieświadomej nienawiści do ojca (kompleks Edypa). Naprawienie relacji z ojcem miałoby wyleczyć polityka z nerwicy.

32 Viktor E. Frankl, Psychotherapy and Existentialim: Selected Papers on Logotherapy (New York: Simon and Schuster, 1967), Fabry, Das Ringen, 41.

${ }^{33}$ Frankl, Grundkonzepte, 17. 
W ciągu pięciu lat leczenia psychonalitycznego wyobraźnia pacjenta została wypełniona przeróżnymi obrazami i symbolami, za którymi przestał widzieć rzeczywistość i których nie potrafił połączyć ze swoim problemem. Po kilku pobytach w gabinecie Frankla stało się jasne, że jego wola sensu była sfrustrowana przez wykonywany zawód i że w rzeczywistości pragnął innego, bardziej sensownego zajęcia. Konflikt sumienia wywoływał w nim wewnętrzny sprzeciw wobec niezgodnych z jego przekonaniami o wartości życia ludzkiego działań rządu, dla którego pracował. Praca, jaką wykonywał, nie wypełniała go sensem, który kształtowałby jego życie. Ostatecznie zrezygnował z wykonywanej pracy i podjął się zajęcia, które nie kolidowało z jego wewnętrznymi przekonaniami i dawało mu poczucie sensu. Pacjent sprawiał wrażenie kogoś psychicznie zaburzonego, w praktyce jednak okazało się, że podłożem jego nerwicy były problemy egzystencjalne.

Lekarz, który jest niezdolny do postawienia tej zróżnicowanej diagnozy, narażony byłby na niebezpieczeństwo pozbawienia się najważniejszej broni, która jest do dyspozycji w psychoterapeutycznym arsenale: zorientowanie człowieka na sens $i$ wartości. Nie mogę sobie wyobrazić, by brak poświęcenia się zadaniu mógł być jedyną przyczyną psychicznego zachorowania. Ale jestem przekonany o tym, że środkiem leczniczym jest pozytywne zorientowanie na sens ${ }^{34}$.

Człowiek potrzebuje zadania, aby sensownie ukształtować swoje życie. Trzeba rozróżnić między zajęciem psychoterapeutycznym a zadaniem, które jest do wykonania, by utrzymać się przy życiu, i zadaniem, które wypełnia życie sensem. Dopiero coś, co nazywamy życiowym zadaniem, może być istotnym nośnikiem naszego życia.

Elisabeth Lukas, uczennica Frankla, opisuje następujący kliniczny przypadek $^{35}$ : w pewnej klinice, zajmującej się terapią nerwic, poznała człowieka, który leżał z ciężką depresją i nie reagował na żadną terapię. Przy rozpoznaniu okazało się, że jego żona uległa przed około 15 laty wypadkowi samochodowemu i od tego czasu wymagała opieki pielęgniarskiej. Trzeba było ją myć, karmić i sadzać na toalecie. Jej mąż przez 14 lat opiekował się nią w domu,

\footnotetext{
${ }^{34}$ Frankl, Ärztliche, 20.

${ }^{35}$ Elisabeth Lukas, Von der Tiefenpsychologie zur Höhenpsychologie. Logotherapie in der Beratungspraxis (Freiburg: Herder, 1983), 298-299.
} 
rezygnując z większych i mniejszych radości. Cały wolny czas poświęcał na opiekę nad żoną. Mimo to przez te 14 lat był zdrowy. Jego dobrzy znajomi ciągle usiłowali go przekonać, że marnuje swoje życie. Argumentowali, że rozsądnym krokiem dla obojga byłoby oddanie żony do domu opieki, gdzie otrzymałaby fachową pomoc. Po 14 latach mężczyzna ugiął się pod namowami znajomych i zdecydował się umieścić żonę w domu opieki. Nie minął rok, kiedy odwieziono go do kliniki psychiatrycznej. Wszelkie zabiegi terapeutyczne i przyjmowanie niemałej ilości medykamentów nie przyniosły żadnego skutku ani poprawy. Nic nie potrafiło go przekonać do zaintersowania się światem i przywrócić go do życia w społeczeństwie. Personel kliniki doszedł do wniosku, że zajmowanie się przez 14 lat żoną i rezygnacja z wielu życiowych przyjemności dokonały w jego psychice ciężkich urazów, które uniemożliwiały mu powrót do społeczności. Diagnoza brzmiała: „Za późno oddał swoją żonę do domu opieki”. Kiedy Elisabet Lukas, podczas wizyty w szpitalu, przypadkowo weszła z nim w rozmowę, nabrała przypuszczenia, że pacjent cierpi na przerażający konflikt wartości, który został wywołany przez podjęcie decyzji wbrew własnemu sumieniu. To przypuszczenie nasuwało się dlatego, ponieważ mężczyzna mógł rozmawiać tylko na temat przywiązania i miłości do swojej żony. Wszystkie inne wartości, na których mógłby budować zdrowe relacje, były dla niego nieważne i uznane za wygasłe. Tylko obraz żony był dla niego żywy. Po rozmowie Elisabeth Lukas przez pół godziny chodziła tam i z powrotem po szpitalnym korytarzu, zmagając się ze swoimi myślami. Następnie wróciła do pokoju chorego i poleciła mu wymeldować się ze szpitala, odstawić medykamenty i jak najprędzej sprowadzić swoją żonę do domu. „Pan nie jest psychicznie ani nerwowo chory, pan przeżywa walkę w sumieniu, i dopóki będzie się pan sprzeciwiał swojemu sumieniu, dopóty nie będzie pan odprężony ani zadowolony”. Mężczyzna spojrzał na nią, odsunął kołdrę i zaczął się ubierać. Od tego czasu Elisabeth Lukas widziała go jeszcze dwa razy: raz u niego w domu, gdzie zaprosił ją pół roku później, i raz w poradni zdrowia psychicznego. Za pierwszym razem zobaczyła witalnego, pogodnego człowieka, który krzątał się troskliwie wokół swojej żony, podczas gdy ona wodziła za nim spojrzeniem pełnym sympatii i miłości. Za drugim razem widziała go w żałobie, gdy wracał z cmentarza od grobu swojej żony. „Gdyby nie Pani”, powiedział, „moje życie byłoby teraz skończone. Mam wrażenie, że nigdy bym tego nie przezwyciężył, gdybym ją 
wtedy zostawił na pastwę losu. Jej samotna śmierć w domu opieki także mnie by zabiła. A tak miała lekką śmierć, a ja znalazłem mój spokój. Dziękuję Pani”.

Nerwica noogenna, chociaż ma źródło w problemach egzystencjalnych, może objawiać się w symptomach chorobowych, typowych dla nerwic psychogennych i somatogennych. „W przeciwieństwie do nerwicy w ściślejszym sensie tego słowa, która przedstawia per definitionem chorobę psychogenną, nerwica noogenna [...] może czasami też znaleźć swój wyraz w symptomatologii neurotycznej"36. Poszczególne typy nerwic nie występują nigdy samodzielnie. „Nie istnieją właściwie żadne czysto somatogenne, psychogennne czy noogenne nerwice, raczej tylko przypadki mieszane" ${ }^{37}$. Nerwice mogą się ze sobą mieszać zarówno ze względu na pochodzenie, jak i występujące objawy. Na przykład w nerwicy psychogennej i somatogennej mogą pojawić się objawy związane z noogennymi zaburzeniami sensu, tzn. z kryzysem sensu. Natomiast w nerwicy noogennej, która objawia się w kryzysie sensu, mogą wystąpić zaburzenia lęku, natręctwa, ataki paniki, depresje lub zaburzenia układu wegetatywnego.

Musimy strzec się przed patologizmem. Ponieważ zwątpienie w sens życia lub w ogóle w życie, zwątpienie w sens - które w gruncie rzeczy leży u podstaw wszelkiego zwątpienia - nie oznacza jeszcze choroby ${ }^{38}$.

Logoterapia zna nie tylko walkę o ludzkie bycie, „lecz także walkę o sens bycia ludzkiego" ${ }^{39}$. Pytania o celowość życia nie mają w sobie niczego patologicznego, „lecz coś na wskroś ludzkiego” ${ }^{40}$. Wątpienie i pytanie o sens jest przypisane do istoty ludzkiej, która mimo wszystko i ponad wszystko szuka sensu, żeby wypełnić nim swoje życie. Skoro Frankl postrzega wolę sensu jako najbardziej ludzki fenomen, to związana $\mathrm{z}$ nią frustracja nie jest jeszcze czymś chorobliwym. Kryzys sensu nie jest zjawiskiem patologicznym, podobnie jak lękliwość nie jest czynnikiem neurotycznie chorobliwym.

\footnotetext{
${ }^{36}$ Frankl, Der Mensch, 143.

${ }^{37}$ Frankl, Theorie, 7.

${ }^{38}$ Frankl, Logotherapie, 119.

${ }^{39}$ Frankl, Ärztliche, 336.

${ }^{40}$ Frankl, Logotherapie, 119.
} 
Nie musi się być chorym, jeżeli uważa się własne bycie jako bezsensowne, a nawet nie musi się z tego powodu zachorować. Egzystencjalna frustracja nie jest zatem czymś chorobliwym ani nie jest w każdym przypadku tym, co może wywołać chorobę; innymi słowy: ona sama w sobie nie jest niczym patologicznym ani nawet czymś w sposób konieczny patogennym, ponieważ jej patogenność jest jedynie fakultatywna. Lecz kiedy stanie się ona faktycznie patogenna ( $p a-$ thogen - wywołująca chorobę), czyli rzeczywiście prowadzi do choroby, to takie nerwice określamy jako nerwice noogenne (noogen - powstałe w duchu $)^{41}$.

Istnieje wąska i płynna granica między wątpieniem a zwątpieniem w sens. O ile teoretycznie można odróżnić zmaganie się z sensem przynależące istocie życia od zmagania, które ma w sobie coś nieuchronnie prowadzącego do kryzysu i załamania, o tyle w praktyce trudno jest określić moment, w którym definitywnie gubi się sens egzystencji, co staje się zagrożeniem dla życia. Zadaniem analizy egzystencji w krytycznej sytuacji, kiedy utrata poczucia sensu prowadzi do próby samobójczej, jest ,apelować do woli życia, dalszego życia i przeżycia" ${ }^{42}$. W sytuacjach granicznych, trudnych analiza egzystencji musi uczynić człowieka zdolnym do znoszenia cierpienia, „odwołując się do jego woli sensu. W tych przypadkach analiza egzystencji jest pościgiem za sensem" ${ }^{43}$. W każdym przypadku chodzi według Frankla o sens jednorazowej sytuacji i jedynej w swoim rodzaju osoby.

Trzeba jasno i wyraźnnie rozpoznać, co może wywołać zaburzenia chorobowe i co podlega chorobie. „Duch nie może zachorować. Ale człowiek może zachorować"44. Nerwice noogenne mają podłoże w problemach egzystencjalnych, ale nie czynią przez to ducha chorym. Z punktu widzenia logoterapii nie istnieje coś takiego, jak choroba duchowa. „Nerwice noogenne są chorobami »z ducha« - lecz nie są chorobami »w duchu«"45. Człowiek może być psychosomatycznie chory, ale nie może być chory duchowo. Duch jest nieobjętym chorobą miejscem, gdzie rodzą się siły sprzyjające powrotowi do zdrowia.

\footnotetext{
${ }^{41}$ Tamże, 120.

${ }^{42}$ Tamże, 122.

${ }^{43}$ Tamże.

${ }^{44}$ Tamże, 149.

${ }^{45}$ Frankl, Theorie, 168.
} 
Frankl jest przeciwny redukowaniu życia duchowego człowieka do czysto psychicznych mechanizmów. Przeprowadza się psychoanalityczne analizy życia i dzieła artystów, myślicieli czy mistyków, sprowadzając ich duchowe (metafizyczne) doświadczenia do procesów psychicznych. Podejrzewa się ich często o psychiczne aberracje, które miałyby określać charakter ich dzieła, jakby to miało jakieś znaczenie. Wyjątkowe dokonania litrerackie Fiodora Dostojewskiego nie tkwiły w jego chorobie nerwowej, a mistyczne wizje Bernadetty Soubiroux nie miały źródła w jej nerwicowych skłonnościach. „Ponieważ zarówno artystyczny wyczyn tej pierwszej, jak również spotkanie (Boga) tej drugiej osoby leży poza płaszczyzną psychiatryczną" ${ }^{36}$. Karen Horney, współtwórczyni (wraz z Erichem Frommem) neopsychonanalizy, rozumie człowieka jako istotę, w której nerwica i zdrowie współwystępują ze sobą, co znaczy, że neurotyk może być w każdym z nas ${ }^{47}$. Społeczne potrzeby: uznania, bycia podziwianym, sukcesu, niezależności, doskonałości, oddziaływania na innych, władzy, podobania się innym, mogą - w teorii osobowości Horney - nie tylko zamienić się w nerwicę, ale też być siłą motywującą do rozwinięcia wyjątkowej osobowości. U wielkich ludzi zwraca się uwagę na cechy osobowości graniczące z nerwicą. Przeważnie to neurotycy budują kulturę. Sposobem, może nie przezwyciężenia, ale dystansowania się do przeciwności losu, jest pogrążenie się w życiu duchowym. „W obozie koncentracyjnym nie można było inaczej wykonać uniku, jak tylko w życie duchowe" ${ }^{38}$. Podobnie w trudnej sytuacji życiowej lub chorobie człowiekowi łatwiej przyjdzie znieść swoje położenie i przetrwać, robiąc odskok w życie duchowe.

Frankl przytacza kliniczny przypadek pacjentki, której neurotyczny lęk okazał się lękiem egzystencjalnym ${ }^{49}$. Podczas stawiania diagnozy powiedziała: „Przytłacza mnie nieskończoność; gubię się w niej; grunt usunął mi się spod nóg, jakbym miała się rozpuścić". Nie zdając sobie z tego sprawy, wypowiedziała myśl już od wieków zaprzątającą głowy filozofów, dla których nieskończona pustka przestrzeni kosmicznej jest odczuciem nieskończonej

\footnotetext{
46 Tamże, 51.

${ }^{47}$ Karen Horney, Der neurotische Mensch in unserer Zeit (Berlin: Kindler: 1988). Cornelis George Boerre, Persönlichkeitstheorien. Karen Horney (1855-1958) (Berlin-New York: Springer, 2006).

${ }^{48}$ Frankl, Logotherapie, 211.

${ }^{49}$ Frankl, Theorie, 164.
} 
pustki własnej duszy ${ }^{50}$. Lęk pacjentki okazuje się lękiem przed nicością, przed unicestwieniem. Nieskończona pustka zajmuje miejsce nicości. Pustka makrokosmosu zdaje się czystą projekcją wewnętrznej pustki egzystencjalnej, pustki mikrokosmosu, odbiciem braku sensownej treści. Jeżeli ludzkie bycie pozbawione jest treści, przedmiotu, który miałby go egzystencjalnie wypełnić, to staje się przedmiotem sam dla siebie, samoprojekcją. Intensywna koncentracja na samym sobie może wywoływać projektywne złudzenia. Lęk pacjentki przerodził się w psychofobię, która - jak się wydaje - mogła doprowadzić ją do choroby psychicznej. Lęk stał się lękiem przed lękiem. Każdy lęk ma źródło w egzystencjalnym lęku przed unicestwieniem. Leczenie wszystkich zaburzeń lękowych musi uwzględniać ten podstawowy lęk przed niebyciem, śmiercią.

Odpowiednio do skomplikowania tego przypadku musiano wprowadzić zróżnicowane postępowanie terapeutyczne. Przeciw dolegliwościom somatycznym wywołanych lękiem zastosowano terapię medykamentami, zasadniczo środkami uspokajającymi. Ponieważ lęk wywoływał psychofobię, która pozbawiona była oparcia w rzeczywistości, zalecono pacjentce, zgodnie z metodą paradoksalnej intencji, zdystansowanie się do swojego lęku, ignorowanie go. Wreszcie egzystencjalny lęk został poddany logoterapii, która dąży do tego, aby dotknięty nerwicą sam się z nią zmierzył. Wówczas może zmienić nastawienie do symptomu i pozostawić go za sobą. Istotnym zabiegiem logoterapeutycznym było doprowadzenie pacjentki do odkrycia konkretnej, osobistej możliwości wypełnienia sensem swojego życia, przepełnionego dotąd lękiem przed niebyciem. Negatywnym celem logoterapii było pokazanie, że lęk pacjentki tkwi głębiej niż to, co psychiczne. Pozytywny cel został zaś osiągnięty przez „wyzwolenie chorej od neurotycznego lęku - mianowicie o tyle, że lęk ten został pozbawiony swojej egzystencjalnej podstawy" ${ }^{1}$. Pacjentka, uwolniona od paraliżującego strachu, mogła znowu poświęcić się swoim życiowym zadaniom. Neurotyczny lęk stał się bezprzedmiotowy, kiedy sens życia został ponownie odkryty.

${ }^{50}$ „Przeraża mnie wieczne milczenie tej nieskończonej przestrzeni”, Blaise Pascal, Pensèe, Edition de Louis Lafuma, Nr. 201. „Tak spogląda człowiek, bezwiednie, na swoją własną pustkę serca jako »nieskończoną pustkę " przestrzeni i czasu”. Max Scheler, Die Stellung des Menschen im Kosmos, Hrsg. von K.-M. Guth (Berlin: Holzinger, 2016), 43.

${ }^{51}$ Frankl, Ärztliche, 224. 
Logoterapia, jako specyficzna terapia nerwic, musi uwzględniać „obraz człowieka duchowego, wolnego i odpowiedzialnego - odpowiedzialnego właśnie za urzeczywistnienie wartości i za spełnienie sensu - obraz człowieka zorientowanego na sens" 52 . Sensem logoterapii jest uświadomienie neurotykowi jego własnej możliwości znalezienia sensu, ponieważ „pozytywne zorientowanie na sens jest środkiem leczniczym"53. Nerwica jest chorobowym przypadkiem bezsensownego życia, jest cierpieniem duszy, która nie znalazła sensu. Psychiczne zdrowie jest właściwą odpowiedzią na pytanie o sens życia ${ }^{54}$. Logoterapeuta nie jest w stanie dać pacjentowi gotowej recepty na sens życia, może jednak „uświadomić, że nasze życie, stosownie do możliwości, w każdych warunkach i okolicznościach jest sensowne i do końca pozostaje sensowne" ${ }^{\text {" }}$. Każdemu człowiekowi, znajdującemu się nawet w najtrudniejszym położeniu, można powiedzieć, że to, co robi dla innych lub dla osiągnięcia własnego spełnienia, ma sens, nawet jeżeli byłyby to proste zadania życiowe. Pokazanie człowiekowi dotkniętemu przez kryzys jego osobistej możliwości znalezienia sensu poprzedza nie tyle psychonalityczne rozeznanie w jego historii życia, ile zorientowanie się w jego świecie wartości i ustalenie jego własnej zdolności do budowania sensu. Zadaniem logoterapii nie jest zmieniać światopogląd człowieka cierpiącego na kryzys sensu. Logoterapeuta, chociaż kieruje się w terapii pewnym obrazem człowieka, musi strzec się przed rzutowaniem na pacjenta własnego światopoglądu, własnego świata wartości i własnej zdolności do wypełniania życia sensem. Logoterapia nie polega na narzuceniu pewnego modelu postępowania, lecz na zmotywowaniu pacjenta do działania: na uświadomieniu neurotykowi odpowiedzialności za swoje życie. „Za sprawą tej odpowiedzialności chory musi samodzielnie przedrzeć się do konkretnego sensu jego osobistego bycia" ${ }^{36}$. Człowiek dotknięty nerwicą powinien o własnych siłach dokonać wykładni swojego bycia jako bycia odpowiedzialnego, czyli sensownego. Kiedy pacjent

\footnotetext{
${ }^{52}$ Frankl, Theorie, 163.

${ }^{53}$ Frankl, Ärztliche, 20.

${ }^{54}$ Frankl powołuje się na liczne studia amerykańskie, które potwierdzają logoterapeutyczną myśl, że zorientowanie na sens jest miarą zdrowia duszy. Kto żyje sensownie, ten jest zdrowszy psychicznie.

${ }^{55}$ Frankl, Logotherapie, 269.

56 Tamże, 151.
} 
uświadomi sobie swoją odpowiedzialność, wtedy zostają mu postawione dwa główne pytania: 1. „Przed kim czuje się odpowiedzialny - np. przed własnym sumieniem albo przed Bogiem - i 2. Za co czuje się odpowiedzialny, tzn. ku jakim konkretnym wartościom się zwraca, kiedy służy, w jakim kierunku zmierza sens jego życia i jakie zadania go wypełniają"57. Podczas pokazywania choremu sensownej drogi logoterapia dokonuje zasadniczego zwrotu w stawianiu pytania o sens życia. „Musimy uczyć i pouczyć człowieka, który zwątpił w sens, że nigdy i przenigdy nie chodzi o to, czego od życia jeszcze możemy oczekiwać, lecz wyłącznie o to, czego życie od nas oczekuje!" ${ }^{8}$ W logoterapeutycznej praxis człowiek z pytającego przemienia się w pytanego. „To nie nam wolno pytać o sens życia - to życie stawia nam pytania, to ono kieruje pytania do nas - a my jesteśmy pytani! Jesteśmy tymi, którzy mają dać odpowiedź" ${ }^{59}$. Pytania, jakie stawia życie, nie są pytaniami, na które mamy odpowiedzieć w przyszłości. Człowiek opanowany kryzysem sensu często nie widzi przed sobą przyszłości i boi się tego, co może ona przynieść. Logoterapia usiłuje skierować jego uwagę na to, co jest teraz. „Teraźniejszość jest bowiem wszystkim, bo kryje w sobie kierowane do nas ciągle nowe pytanie"60. Jesteśmy niewolnikami myślenia o dalszej lub bliższej przyszłości, dlatego nie potrafimy dawać sensownej odpowiedzi na pytania, jakie w każdej chwili i w każdej sytuacji kieruje do nas życie.

\section{Noodynamika jako dynamika urzeczywistniania wartości przez wypełnianie sensu}

Poszukiwanie sensu stawia niełatwe zadanie przed człowiekiem w dzisiejszym świecie, w którym usiłuje się zaspokoić wszystkie ludzkie potrzeby i jednocześnie stwarza się ciągle nowe, wychodząc im na przeciw, aby je zaspokoić. „Tylko najbardziej ludzka ze wszystkich ludzkich potrzeb, potrzeba

\footnotetext{
57 Tamże, 21.

${ }^{58}$ Viktor E. Frankl, ...trotzdem Jazum Leben sagen.Ein Psychologeerlebt das Konzentrationslager (München: Kösel, 2008), 125.

${ }^{59}$ Frankl, Die Sinnfrage, 88.

${ }^{60}$ Tamże, 89.
} 
sensu, pozostaje w tym wszystkim niezaspokojona"61. Potrzeba sensu nie jest jakąś szczególną czy wyższą potrzebą, którą należałoby zaspokoić w pierwszej kolejności. „Zaspokojenie niższych potrzeb nie jest w żadnym wypadku warunkiem koniecznym walki o sens" ${ }^{\prime 2}$. Potrzeba sensu jest jakościowo inną potrzebą, „luksusową," niemieszczącą się w żadnej kategorii znanych potrzeb. Jej zaspokojenie nie jest dopełnieniem zaspokojenia niższych i wyższych potrzeb. W każdym położeniu życiowym człowiek może wypełnić swoją potrzebę sensu. Logoterpeutyczna praxis potwierdza, że ludzie szukają sensu nawet wtedy, kiedy odczuwają niedostatki w zaspokajaniu potrzeb życiowych. Poszukiwanie sensu nie jest szukaniem szczęścia. „Jeżeli człowiek znajdzie sens, to wtedy (i w zasadzie tylko wtedy) jest szczęśliwy" ${ }^{63}$. Znalezienie sensu rzuca nowe światło na własne życie i zmienia spojrzenie na świat oraz życie innych. Wypełnia człowieka sensotwórczą siłą i otwiera nowe możliwości sensownego ukształtowania własnego życia. Sens rodzi sens. „Jeżeli człowiek znalazł sens, to, jeśli zaszłaby taka konieczność, jest gotowy z czegoś zrezygnować, przyjąć na siebie cierpienie, ponieść ofiarę, a nawet ofiarować

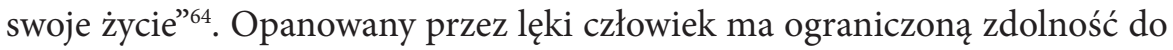
poświęcania swojego życia na rzecz czegoś wartościowego. Kto nie znalazł sensu, ten lekceważy życie i może je mieć w pogardzie. Jeżeli człowiek „nie zna żadnego sensu życia, to gwiżdże na życie"65. Nawet jeżeli komuś takiemu dobrze się powodzi, to w pewnych okolicznościach może odrzucić życie. Mimo zaspokojenia potrzeb życiowych ludzie zdrowi fizycznie i psychicznie nie widzą możliwości „znalezienia w swoim życiu sensu i wypełnienia go sensem" ${ }^{\prime 6}$. Kryzys sensu może dotknąć każdego, bez wyjątku, niezależnie od tego, kim jest, jak żyje i co robi ${ }^{67}$. Podobnie jest ze znalezieniem sensu:

\footnotetext{
${ }^{61}$ Frankl, Logotherapie, 268.

${ }^{62}$ Frankl, Die Sinnfrage, 45.

${ }^{63}$ Tamże, 33.

${ }^{64}$ Frankl, Logotherapie, 236.

${ }^{65}$ Frankl, Die Sinnfrage, 33.

${ }^{66}$ Frankl, Der Mensch, 144.

${ }^{67}$ Frankl przytacza sprawozdanie dyrektora jednego z psychoterpeutycznych centrów Nowego Yorku; wielu jego pacjentów uskarżało się na brak sensu: „they have a good job, they are successful but they want to kill themselves, because they find life meaningless” („mają oni dobrą pracę, odnoszą sukcesy, ale chcą się zabić, ponieważ uważają życie za bezsensowne"). Frankl, Logotherapie, 260.
} 
Sens w życiu można znaleźć zasadniczo niezależnie od przynależności płciowej człowieka i od jego wieku, od poziomu inteligencji i od stopnia wykształcenia, od jego charakteru i od jego otoczenia. W końcu dało się też wykazać, że człowiek może znaleźć sens niezależnie od tego, czy jest religijny czy nie, i w przypadku, kiedy jest on religijny, znowu niezależnie od tego, do jakiego wyznania należy ${ }^{68}$.

Sens jest zawsze tym samym sensem. Nie ma sensu lepszego i gorszego, ważnego i mniej ważnego. To, co robi artysta rzeźbiarz, nie jest bardziej sensowne od tego, co robi stolarz. To, co robi sprzątaczka, nie jest mniej sensowne niż to, co robi lekarz. Nie można robić czegoś bardziej lub mniej sensownego z tytułu wykonywanej profesji lub użyteczności społecznej. We wszystkich wykonywanych zadaniach życiowych człowiek zawsze poszukuje sensu i może go tak samo wypełnić.

Najpierw moje życie może stać się sensowne przez to, że dokonuję czegoś, że tworzę dzieło; ale także przez to, że coś przeżywam - coś albo kogoś przeżywam; albo przeżywam kogoś w jego jedyności i jednorazowości, w kochaniu go. W końcu nasze życie okazuje się sensowne także wtedy, gdy jesteśmy konfrontowani z losem, który nie daje się zmienić, powiedzmy, z nieuleczalną chorobą, a więc także wtedy, gdy jako bezbronne ofiary jesteśmy postawieni w beznadziejnej sytuacji, także wtedy i właśnie wtedy życie pozwala się ciągle jeszcze sensownie kształtować ${ }^{69}$.

Z punktu widzenia logoterapii egzystencja może rozwijać się jako sensowna (sinnvoll) lub bezsensowna (sinnlos $)^{70}$. Sensowność jest kryterium, jeżeli tak można powiedzieć, zdrowia egzystencji. Logoterapia usiłuje określić warunki sensownej (zdrowej) egzystencji. „W praktyce logoterapia zmierza do konfrontacji egzystencji z logosem"71. Duch ludzki, sens, wartości należą do jednego porządku, porządku logosu. Człowiek jako duchowa egzystencja spotyka się z wartościami, aby przez ich doświadczenie wypełnić się sensem. „Jesteśmy przekonani, że istotną cechą ludzkiej egzystencji jest trwanie

\footnotetext{
${ }^{68}$ Tamże, 237.

69 Tamże.

${ }^{70}$ To rozróżnienie nawiązuje do Heideggera właściwej (eigentlich) i niewłaściwej (uneigentlich) egzystencji.

${ }^{71}$ Frankl, Ärztliche, 108.
} 
w polu napięcia między byciem i powinnością, stanie w obliczu sensu i wartości, pddanie się ich wyzwaniu"72. Sens zostaje wypełniony przez urzeczywistnienie możliwości bycia, w poddaniu się wymaganiu, jakie stawia przed człowiekiem spotkanie z wartościami. Ucieczka przed wyzwaniem wartości jest w logoterapii określana „neurotycznym eskapizmem”. Człowiek z obawy przez zakłóceniem wewnętrznej równowagi, regulowanej zasadą homeostazy, ucieka przed konfrontacją z sensem i wartościami.

Wiadomo, że organ, który nie będzie absorbowany i obciążany, ulega z biegem czasu atrofii, zanikowi. „Medycyna dzisiejsza wie, że nie tylko przeciążenie odbija się patogennie na zdrowiu człowieka, wywołuje chorobę, lecz równie dobrze odciążenie może mieć taki wpływ"73. Istnieje, według Frankla, nie tylko patologia stresu, ale również „patologia odciążenia (Pathologie der Entlastung)"74.

Jednak człowiek potrzebuje napięcia, a najbardziej sprzyja mu takie napięcie, które powstaje pomiędzy dwoma biegunami: człowiekiem z jednej strony a celem, który sobie stawia, zadaniem przez siebie wyznaczonym $z$ drugiej strony ${ }^{75}$.

Kto dziś wymaga czegoś od siebie? Czy raczej obecnie nie jest tak, że każdy czuje się przytłoczony wymaganiami? Czy ktoś w dzisiejszych czasach nie narzeka na stres? „Przy tym zapomina się, że Hans Seyle, bądź co bądź twórca nauki o stresie, wyraźnie rozróżnia między distress i eustress, to znaczy między stresem wywołującym chorobę a stresem utrzymującym przy zdrowiu"76. Brak zdrowego stresu wyzwala egzystencjalną frustrację, w której człowiek pozbawiony jest wyzwań. Potrzebujemy wyzwań, aby nie popaść w stan niemocy egzystencjalnej. Umiejętność stawiania czoła wyzwaniom nie jest dana, lecz musi być wyćwiczona i wypracowana. „To, czego człowiek naprawdę potrzebuje, to nie stan pozbawiony napięcia, lecz raczej pewna, zdrowa, dawka napięcia - taka dawka napięcia, jaką wywołuje bycie wyzwanym i zaabsor-

\footnotetext{
72 Tamże.

${ }^{73}$ Viktor E. Frankl, Bergerlebnis und Sinnerfahrung (Innsbruck-Wien: Tyrolia, 2013), 15.

${ }^{74}$ Frankl, Ärztliche, 20.

${ }^{75}$ Frankl, Bergerlebnis, 17.

${ }^{76}$ Tamże, 13.
} 
bowanym przez sens"77. Nowoczesne społeczeństwo, nazywane „społeczeństwem przyjemności" (Spaßgesellschaft), nie jest wolne od neurotycznych dolegliwości. Zasada przyjemności, zalecana przez psychoterapetów jako najlepsza droga do uzyskania równowagi psychicznej, nie sprawdziła się. Tak jak medycyna w obliczu wzmagających się chorób cywilizacyjnych musi zmieniać strategie leczenia, tak też psychiatria wobec cywilizacyjnego wrostu nerwic, szczegółnie nerwic połączonych z kryzysem sensu, musi obierać nowe strategie terapii i higieny psychicznej. „W psychoterapii era epikurejska dobiega końca i zostaje zastąpiona przez erę stoicką"78. Człowiek nie dochodzi do równowagi wewnętrznej przez uwalnianie się od tego, co nieprzyjemne, i koncentrowanie się na tym, co przyjemne. Nowoczesna psychoterapia przywrócenie i utrzymanie równowagi psychicznej widzi w stawianiu wymagań, dla których szukanie przyjemności jest mniej ważne. Sposobem na zachowanie lub odzyskanie zdrowia zawsze jest asceza, niezależnie od tego, o jaki aspekt zdrowia chodzi. „Przyjemność sama w sobie jest niczym, co mogłoby dać sens byciu ludzkiemu, tak więc brak przyjemności także nie jest w stanie odebrać życiu sens"79. Nic nie utrwala się w człowieku tak mocno, jak poczucie sensu. Nie musimy odmawiać sobie przyjemności, aby żyć sensownie. Przeżycia zadowolenia i szczęścia nabierają szczególnego smaku, kiedy towarzyszą poszukiwaniu sensu. Tracą znaczenie, kiedy przychodzi kryzys sensu.

Każda istota żywa potrzebuje napięcia, które zmotywuje je do życia. Każda dynamika rodzi się z wewnętrznej siły, wyzwalanej przez zewnętrzne czynniki. Biodynamika oznacza dynamikę rozwoju roślin, które do wzrostu potrzebują nie tylko odpowiedniego położa i wody, ale też światła. Potrzeba światła potrafi tak zdynamizować niektóre rośliny w lesie deszczowym, że przebijają się nawet kilkadziesiąt metrów w górę. Potrzeba zachowania życia skłania wszystkie żywe istoty do wypatrywania celów, które uwalniają w nich dynamikę działania. Psychodynamika oznacza dynamikę, która określa ludzkie działania nie tylko na rzecz zachowania samego życia, ale także na rzecz zrealizowania innych życiowych celów. Egzystencja ludzka nastawiona na poszukiwanie sensu potrzebuje jeszcze innej dynamiki. „Dynamika, która

\footnotetext{
${ }^{77}$ Frankl, Ärztliche, 21.

78 Tamże.

${ }^{79}$ Frankl, Die Sinnfrage, 87.
} 
utrwala się w biegunowym polu napięcia między byciem i powinnością, jest nazywana w logoterapii, w przeciwieństwie do wszelkiej psychodynamiki, noodynamiką" ${ }^{\circ 0}$. Noodynamika jest dynamiką bycia ludzkiego, które w spotkaniu $\mathrm{z}$ wartościami uwalnia wewnętrzne zobowiązanie do ich urzeczywistnienia. W psychodynamice człowieka jest napędzany przez popędy i kierowany potrzebami, natomiast $\mathrm{w}$ noodynamice jest on ożywiany pragnieniem sensu i pociągany przez wartości. Im intensywniejsze przeżycie wartości i pragnienie sensu, tym wyższe napięcie związane z poszukiwaniem sensu. „Im bardziej zredukowane jest napięcie, które wypływa z noodynamiki, tym bardziej człowiek jest zagrożony i znajduje się w niebezpieczeństwie" ${ }^{\prime 1}$. Uznawanie czegoś za wartościowe i poświęcanie się czemuś potrzebuje nieustannie noodynamicznego napięcia niezbędnego do wypełniania życia sensem. Kiedy napięcie opada, gaśnie duchowa dynamika i pojawia się zagrożenie kryzysem sensu.

Według logoterapii człowiek jest istotą ukierunkowaną nas sens (sinnorientiert). Sens pozostaje punktem orientacyjnym w każdych warunkach i okolicznościach życia człowieka. Bycie sensu wyprzedza sens bycia. Istotą sensu jest „bycie incjatorem bycia” ${ }^{2}$. Aby wyjaśnić, czym jest sens przewodni dla bycia ludzkiego, Frankl powołuje się na biblijny obraz Boga, który kroczy w postaci chmury, torując narodowi wybranemu drogę przez pustynię, dzięki czemu może on urzeczywistnić sens swojej wędrówki, docierając do Ziemi Obiecanej. W Mojżeszu Frankl widzi przewodnika, który nie chce łatwymi obietnicami uspokajać ducha swojego narodu, niepewnego swego losu w czasie wędrówki przez pustynę, lecz stawia przed nim wyzwanie i wymaganie. Zstąpiwszy z góry Synaj, Mojżesz przekazuje narodowi wybranemu Boże przykazania, doprowadzając $\mathrm{w}$ ten sposób do konfrontacji $\mathrm{z}$ wartościami, których urzeczywistnienie połączone $\mathrm{z}$ napięciem, wywołanym Bożą obecnością, wypełni życie sensem.

Logoterapia została rozwinięta po to, by leczyć nerwice, zwłaszcza nerwice noogenne. Rozwijając możliwości terapii nerwic związannych z kryzysem sensu, logoterapia pozwoliła nam zobaczyć człowieka w nowym świetle -

\footnotetext{
${ }^{80}$ Frankl, Ärztliche, 108.

81 Tamże, 109.

${ }^{82}$ Tamże, 114.
} 
nie tylko jako człowieka neurotycznego, lecz jako człowieka w sobie, z jego wewnętrznymi zmaganiami, z jego porażkami i z jego zwycięstwami w nieustannym dążeniu do sensu.

\section{Bibliografia}

Allers Rudolf. 1979. Das Werden der sittlichen Person. Wildesheim-New York: Georg Olms.

Allers Rudolf. 2008. Abnorme Welten. Ein phänomenologischer Versuch zur Psychiatrie. Hrsg., kommentiert und eingeleitet von Alexander Battyany. Weinheim-Basel: Beltz.

Batthyany Alexander. 2017. Die Überwindung der Gleichgültigkeit. Sinnfindung in einer Zeit der Wandlung. München: Kösel.

Böschemeyer Uwe. 1977. Die Sinnfrage in der Psychotherapie und Theologie. Die Existenzanalyse und Logotherapie Viktor Frankls aus der theologischen Sicht. Berlin: De Gruyter.

Bühler Charlotte. 1933. Der menschliche Lebenslauf als psychologisches Problem. Leipzig Hirzel.

Fabry Josef. 1973. Das Ringen um Sinn. Stuttgart: Paracelsus.

Fabry Josef. 1983. Wege zur Selbstfindung: wie man jedem Tag seinen Sinn gibt. Basel-Wien: Herder.

Frankl Viktor E. 1967. Psychotherapy and Existentialism: Selected Papers on Logotherapy. New York: Simon and Schuster.

Frankl Viktor E. 1980. Psychotherapie für den Laien. Freiburg-Basel-Wien: Herder.

Frankl Viktor E. 1982. Die Psychotherapie für den Alltag. Wien: Franz Deuticke.

Frankl Viktor E. 1997. Die Psychotherapie in der Praxis. Eine kasuistische Einführung für Ärzte. München: Piper.

Frankl Viktor E. 1997. Die Sinnfrage in der Psychotherapie. München: Piper.

Frankl Viktor E. 2005. Ärztliche Seelsorge. Grundlagen der Logotherapie und Existenzanalyse. Mit den "Zehn Thesen über die Person". Wien: Paul Zsolnay.

Frankl Viktor E. 2002. Was nicht in meinen Büchern steht. Lebenserinnerungen, Weinheim: Beltz.

Frankl Viktor E. 2005. Der leidende Mensch. Anthropologische Grundlagen der Psychotherapie. Bern: Hans Huber.

Frankl Viktor E. 2007. Theorie und Therapie der Neurosen. Einführung in Logotherapie und Existenzanalyse, München-Basel: Ernst Reinhardt.

Frankl Viktor E. 2008. Bergerlebnis und Sinnerfahrung, Innsbruck-Wien: Tyrolia. 
Frankl Viktor E. 2009. Das Leiden am sinnlosen Leben. Psychotherapie für heute, Freiburg im Breisgau: Herder.

Frankl Viktor E. 2009. Der Mensch vor der Frage nach dem Sinn. München: Piper. Frankl Viktor E. 2009. Trotzdem ja zum Leben sagen. Ein Psychologe erlebt das Konzentrationslager. München: Kösel.

Frankl Viktor E. 2010. Logotherapie und Existenzanalyse. Weinheim-Basel: Beltz.

Frankl Viktor E. 2015. Es kommt der Tag, da bist du frei. Unveröffentlichte Texte und Reden. München: Kösel.

Frankl Viktor E. 2015 Grundkonzepte der Logotherapie. Wien: Facultas.

Frankl Viktor E. 2016. Der Wille zum Sinn. Bern: Hogrefe.

Frankl Viktor E. 2017. Der unbewußte Gott. Psychotherapie und Religion. München: Kösel.

Frankl Viktor E. 2017. Wer ein Warum zum Leben hat. Lebenssinn und Resilienz. Weinheim-Basel: Beltz.

Frankl Viktor E., Kreuzer Franz. 1982. Im Anfang war der Sinn. Von der Psychoanalyse zur Logotherapie. Ein Gespräch. Franz Deuticke Verlag, Wien: Franz Deuticke.

Frankl Viktor E., Lapide Pinhas. 2007. Gottsuche und Sinnfrage, Gütersloher Verlagshaus, Gütersloh: Gütersloher Verlagshaus.

Freud Sigmund. 1960. Briefe 1873-1939. Hrsg. Ernst L. Freud. Frankfurt am Main: S. Fischer.

Heidegger Martin. 2004. Die Grundbegriffe der Metaphysik. Gesamtausgabe. Band 29/30. Hrsg. von Friedrich - Wilhelm von Herrmann. Frankfurt am Main: Vittorio Klostermann.

Horney Karen, 1988. Der neurotische Mensch in unserer Zeit. Berlin: Kindler.

Janet Pierre, Raymond Fulgence. 2010. Les obsessions et la psychasthenie. Paris: Nabu Press.

Längle Alfried. 2007. Sinnvoll leben. Eine praktische Anleitung der Logotherapie. St. PöltenSalzburg: Residenz.

Längle Alfried. 2013. Viktor Frankl - eine Begegnung. Wien: Facultas.

Lukas Elisabeth. 1980. Auch das Leben hat Sinn. Logotherapeutische Wege zur Gesundung. Freiburg: Herder.

Lukas Elisabeth. 1983. Von der Tiefenpsychologie zur Höhenpsychologie. Logotherapie in Beratunsgpraxis. Freiburg im Breisgau: Herder.

Lukas Elisabeth. 2004. Logotherapeutische Antworten auf die existentielle Fragen. München: Profil.

Lukas Elisabeth. 2005. Viktor E. Frankl. Arzt und Philosoph. München: Profil.

Lukas Elisabeth. 2006. Lehrbuch der Logotherapie. Menschenbild und Methoden. München: Profil.

Lukas Elisabeth. 2011. Der Schüssel zu einem sinnvollen Leben. Die Höhenpsychologie Viktor E. Frankls. München: Kösel. 
Michalski Karol. 2017. „Sens w logoterapii i analizie egzystencji Viktora E. Frankla“. Kwartalnik Filozoficzny 3: 105-133.

Michalski Karol. 2018. „Poszukiwanie sensu według logoterapii i analizy egzystencji Viktora E. Frankla". Studia z Historii Filozofii 2(9): 143-170.

Psychiatrie in Darstellungen. 1973. Ludwig Jakob Pongratz (Hrsg), Bern-Stuttgart-Wien: Hans Huber.

Raskob Hedwig. 2006. Die Existenzanalyse und Logotherapie Frankls, München: Springer.

Richter Horst-Eberhard. 1995. Hoffnung auf einen neuen Weg sich selbst und andere zu befreien. Hamburg: Rowohlt.

Viktor Frankl und die Philosophie. 2005. Battyany Dominik, Zsok Otto (Hrsg.), Wien-New York: Springer.

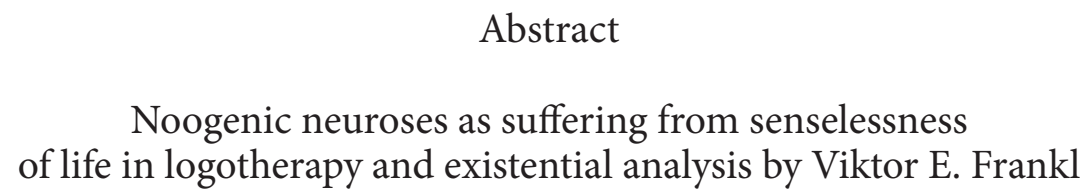

There are existential crises that run under the clinical picture of neurosis, without being neurosis in the narrower sense of the word, namely, in the sense of a psychogenic disease. It can be seen from the psychotherapeutic practice that a person who is under the pressure of a mental problem or experiences the tension of a conflict of conscience can develop a disease, neurotic in the common sense of the word. The noogenic neuroses arise from the spiritual and thus require a therapy that starts where the neurosis is rooted. Such a therapy was called logotherapy, a therapy of mental existence, by Frankl.

Keywords: Frankl; logotherapy; neurosis; noogenic neurosis; crisis of meaning; psychotherapy.

\section{Streszczenie}

Nerwice noogenne jako cierpienie na bezsens życia w logoterapii i analizie egzystencji Viktora E. Frankla

Istnieją kryzysy egzystencjalne, których przebieg mieści się w klinicznym obrazie nerwicy, chociaż nie mogą być zaliczane do nerwic w węższym znaczeniu tego słowa, $\mathrm{w}$ sensie zaburzenia psychicznego. Logoterapeutyczna praxis pokazuje, że osoba, która jest pod presją duchowego problemu lub konfliktu sumienia, może 
zachorować na nerwicę w potocznym znaczeniu - Frankl nazywa ją nerwicą noogenną lub noetyczną. Nerwice nooogenne powstające w obszarze duchowym wymagają odpowiedniej terapii, która w pierwszej kolejności musi odnieść się do spraw duchowych. Psychoterapię zajmującą się kryzysami duchowej egzystencji Frankl określa logoterapią.

Słowa kluczowe: Frankl; analiza egzystencji; logoterapia; nerwice noogenne; wola sensu; noodynamika. 